\title{
Anakinra after treatment with corticosteroids alone or with tocilizumab in patients with severe COVID-19 pneumonia and moderate hyperinflammation. A retrospective cohort study: comment
}

\author{
Sadık Yurttutan ${ }^{1} \cdot$ Utku Ufuk Gullu $^{2} \cdot$ Sevcan Ipek $^{3}$
}

Received: 14 January 2021 / Accepted: 2 February 2021 / Published online: 18 February 2021

(c) Società Italiana di Medicina Interna (SIMI) 2021

\section{Dear Editor,}

We read the study by Aomar-Millan et al. with great interest. The article discusses the use of immuno-suppressive treatment in severe pneumonia and hyperinflammation caused by Sars-Cov-2 in adults. The article shows that Anakinra, which is an IL-1 receptor blocker and selective immuno-suppressive, is very effective in preventing Sars-Cov-2 related tissue damage and aftereffects caused by an uncontrolled and exaggerated immune response [1]. Anakinra is an IL-1 receptor blocker that has had longtime use in the treatment of various autoimmune diseases in adults. Anakinra is occasionally used to treat autoimmune disease in children, although there is little clinical experience compared to adults [2]. Furthermore, there is limited data in the literature regarding the use of Anakinra in the severe course of pediatric Sars-Cov-2 cases.

It is well known that Sars-Cov-2 typically has a mild clinical course in children. As the reasons for the mild course in children; it has been speculated that there are differences in ACE-2 receptor expression, seasonal coronavirus exposure, effective regulatory $\mathrm{T}$ cell functions associated with the effective thymus gland [3].

Sadık Yurttutan

dryurttutan@gmail.com

1 Division of Neonatology, Department of Pediatrics, Faculty of Medicine, Kahramanmaras Sutcu Imam University, Avsar Campus, 46100 Kahramanmaras, Turkey

2 Division of Pediatric Cardiology, Department of Pediatrics, Faculty of Medicine, Kahramanmaras Sutcu Imam University, Kahramanmaras, Turkey

3 Division of Pediatric Intensive Care Unit, Department of Pediatrics, Faculty of Medicine, Kahramanmaras Sutcu Imam University, Kahramanmaras, Turkey
However, the clinical picture that has recently been observed in pediatric patients, which arises due to SarsCov-2 related immune dysregulation, has been defined as the multisystem inflammatory syndrome-children (MISC). Mild Cardiac involvement, acute phase elevation, and short-lasting fever often accompany these cases. Occasionally, septic shock and severe cardiac involvement can also be observed in the cases [4].

We would like to share an 8-year-old child case hospitalized in our clinic and treated with Anakinra after being diagnosed with Sars-Cov-2 related MIS-C. An 8-year-old female with no known illness was admitted to our clinic with fever, headache, and abdominal pain.

Based on the patient's clinical history, she had a fever for 3 days, and her parents were diagnosed with Sars-Cov-2 10 days prior. On the second day of hospitalization, her blood pressure $(80 / 50 \mathrm{mmhg})$ decreased and her clinical status deteriorated; she was transferred to the pediatric intensive care unit. Echocardiography showed that ejection fraction and fractional shortening were $44 \%$ and $22 \%$, respectively. Dobutamine treatment was initiated for the patient. SARS-CoV-2 IgG testing was detected as positive. MIS-C was considered in this patient due to fever lasting more than 3 days, SARS-CoV-2 IgG positivity, elevated inflammation markers (CRP: $171 \mathrm{mg} / \mathrm{L}$, procalcitonin: $53 \mathrm{mcg} / \mathrm{L}$ ), maculopapular rash on the body, and bilateral nonpurulent conjunctivitis. Enoxaparin was started because of high D-dimer levels. Due to the lack of improvement in the patient's clinical and laboratory findings, intravenous immunoglobulin was administered. Adrenaline and milrinone were added to the patient's treatment plan due to decreased cardiac functions. Steroid was given as a pulse dose. Anakinra was added to the patient's treatment plan at a dose of $8 \mathrm{mg} / \mathrm{kg} /$ day due to persistent fever, a high vasoactive score and lack of improvement in clinical status while being monitored. Anakinra was 
Table 1 Treatments, laboratory and echocardiographic findings during the follow-up of the patient in the pediatric intensive care unit

\begin{tabular}{|c|c|c|c|c|c|c|c|c|c|c|}
\hline & 1. day & 2. day & 3. day & 3. day & 4. day & 5.day & 6. day & 7.day & 8. day & 13. day \\
\hline $\mathrm{EF}(\%)$ & 44 & 67 & 53 & 52 & 62 & 66 & 64 & & & 76 \\
\hline $\mathrm{FS}(\%)$ & 22 & 37 & 22 & 36 & 33 & 36 & 34 & & & 44 \\
\hline Pericardial effusion & + & + & + & + & - & - & & & & \\
\hline Mitral insufficiency & Mild & Mild & Mild & Mild & - & - & & & & \\
\hline Dobutamin $(\mathrm{mcg} / \mathrm{kg} / \mathrm{m})$ & 10 & 15 & 15 & 7.5 & 5 & Stop & & & & \\
\hline Adrenalin $(\mathrm{mcg} / \mathrm{kg} / \mathrm{m})$ & & & 0.1 & 0.1 & 0.1 & Stop & & & & \\
\hline Milrinon $(\mathrm{mcg} / \mathrm{kg} / \mathrm{m})$ & & & 0.25 & 0.25 & 0.25 & 0.25 & 0.125 & & Stop & \\
\hline IVIG (g/kg) & 1 & 1 & & & & & & & & \\
\hline Anakinra (mg/kg/day) & & & & & 8 & 8 & 8 & 8 & & \\
\hline LMWH) & + & + & + & + & + & + & + & + & + & + \\
\hline Methlyprednisolon $(\mathrm{mg} / \mathrm{kg})$ & 2 & 2 & 30 & 30 & 30 & 2 & 2 & 2 & & \\
\hline ProBNP (ng/L) & 5935 & 6340 & 6280 & 4564 & 3280 & 1570 & 755 & 252 & 226 & $<70$ \\
\hline Troponin I (mcg/L) & 0.07 & 0.03 & 0.02 & 0.02 & $<0.01$ & $<0.01$ & $<0.01$ & $<0.01$ & $<0.01$ & $<0.01$ \\
\hline $\mathrm{CRP}(\mathrm{mg} / \mathrm{L})$ & 171 & 173 & 110 & 121 & & 75 & 40 & 9.8 & 3.4 & 3.4 \\
\hline Procalcitonin (mcg/L) & 53 & 28 & 9.52 & 41 & 4. 3 & 0.3 & & & & 0.04 \\
\hline
\end{tabular}

$E F$ ejection fraction, FS Fractional shortening, $I V I G$ intravenous immune globulin, $L M W H$ low molecule weight heparine, ProBNP pro-brain natriuretic peptide, $C R P$ C-reactive protein, $m g$ miligram, $m c g$ microgram, $k g$ kilogram, $m$ minutes, $L$ liter ,

administered subcutaneously to the patient in four doses. After Anakinra treatment, the patient's cardiac functions immediately improved. Inotropic support was reduced and stopped. The patient's fever subsequently receded to normal ranges. The patient recovered completely and was discharged on the 14th day of hospitalization with aspirin therapy. No pathological finding was observed in the echocardiograms performed during the 1.5-month follow-up of the patient. Table 1 displays the clinical follow-up characteristics of the patient as well as the treatments given.

In the literature, two cases similar to our patient were shared in a contemporary publication. In the publication by Calò Carducci FI et al., Anakinra was given in two pediatric cases who were successfully treated [5]. Although SarsCov-2 findings are milder in pediatric patients compared to adults, MIS-C may be rarely observed, but can be very serious. There has been recent publications on Anakinra treatment in severe MIS-C cases in the literature.

Anakinra is a selective and powerful immunomodulatory agent. Recent studies have speculated that the uncontrolled immune response triggered by the IL-1 receptor and the subsequent endothelial damage is determinant in the pathogenesis of MIS-C. In our case, there was insufficient clinical improvement despite steroid and IVIG treatments. Thereafter, the patient was treated with Anakinra, an IL-1 receptor blocker, and her clinical status rapidly improved, making it possible to terminate supportive treatment. The successful treatment of our case supports the speculation that IL-1 plays a key role in the pathogenesis of MIS-C, and may potentially be a treatment target.
We successfully used Anakinra in a severe case of MIS-C in our clinic. We intended to emphasize that the use of Anakinra should be considered in pediatric cases with severe MIS-C that is resistant to standard immunosuppressive therapy (steroid, IVIG, etc.), as well as adult cases with a severe clinical course.

Best regards.

Acknowledgements None.

Funding The authors declared that this case has received no financial support.

\section{Compliance with ethical standards}

Conflict of interest No conflict of interest was declared by the authors.

\section{References:}

1. Aomar-Millán IF, Salvatierra J, Torres-Parejo Ú, Faro-Miguez N, Callejas-Rubio JL, Ceballos-Torres Á, Cruces-Moreno MT, Gómez-Jiménez FJ, Hernández-Quero J, Anguita-Santos F (2021) Anakinra after treatment with corticosteroids alone or with tocilizumab in patients with severe COVID-19 pneumonia and moderate hyperinflammation A retrospective cohort study. Intern Emerg Med. 5:1-10. https://doi.org/10.1007/s11739-020-02600-z (Epub ahead of print. PMID: 33400157; PMCID: PMC7782569.) 
2. Vastert SJ, Jamilloux Y, Quartier P, Ohlman S, Osterling Koskinen L, Kullenberg T, Franck-Larsson K, Fautrel B, de Benedetti F (2019) Anakinra in children and adults with Still's disease. Rheumatology (Oxford) 58(Suppl 6):vi9-vi22. https://doi. org/10.1093/rheumatology/kez350 (PMID: 31769856; PMCID: PMC6878842)

3. Güneş H, Dinçer S, Acıpayam C, Yurttutan S, Özkars MY (2020) What chances do children have against COVID-19? Is the answer hidden within the thymus? Eur J Pediatr 13:1-4

4. Henderson LA, Canna SW, Friedman KG et al (2020) American College of Rheumatology Clinical Guidance for pediatric patients with multisystem inflammatory syndrome in children (MIS-C) associated with SARS-CoV-2 and hyperinflammation in COVID19. Version 2. Arthritis Rheumatol. https://doi.org/10.1002/ art.41616 (Epub ahead of print. PMID: 33277976.)
5. Calò Carducci FI, De Ioris MA, Agrati C et al (2020) Hyperinflammation in two severe acute respiratory syndrome coronavirus 2-infected adolescents successfully treated with the interleukin-1 inhibitor anakinra and glucocorticoids. Front Pediatr 30(8):576912. https://doi.org/10.3389/fped.2020.576912 (PMI D:33330276;PMCID:PMC7734022)

Publisher's Note Springer Nature remains neutral with regard to jurisdictional claims in published maps and institutional affiliations. 